Article

\title{
VOX Spain: The Organisational Challenges of a New Radical Right Party
}

\author{
Astrid Barrio ${ }^{1, *}$, Sonia Alonso Sáenz de Oger ${ }^{2}$ and Bonnie N. Field ${ }^{3}$ \\ ${ }^{1}$ Department of Constitutional Law and Political Science, University of Valencia, Spain; E-Mail: astrid.barrio@uv.es \\ 2 International Politics, Georgetown University in Qatar, Qatar; E-Mail: sa1197@georgetown.edu \\ ${ }^{3}$ Department of Global Studies, Bentley University, USA; E-Mail: bfield@bentley.edu \\ * Corresponding author
}

Submitted: 22 April 2021 | Accepted: 2 August 2021 | Published: 24 November 2021

\begin{abstract}
This article examines the organisation of VOX, a new radical right party in Spain. It shows that the party has taken early and uneven steps to build a mass organisation and initially opted for open membership recruitment with participatory organisational elements. Also, the party's rapid growth and quick entrance into political institutions at different state levels led the party leadership to establish more centralised control and limit members' prerogatives, though recruitment continued. Centralisation in part responds to organisational needs given the party's quickly acquired political relevance, but also to the desire of the central party leadership to forestall the articulation of territorial interests, or prevent them from escaping their control. Today, VOX exhibits elements of mass party organisation and highly centralised decision-making in the hands of national party leaders.
\end{abstract}

\section{Keywords}

party organisation; political parties; radical right; Spain; Vox

Issue

This article is part of the issue "Right-Wing Populist Party Organisation Across Europe: The Survival of the Mass-Party?" edited by Daniele Albertazzi (University of Surrey, UK) and Stijn van Kessel (Queen Mary University of London, UK).

(C) 2021 by the authors; licensee Cogitatio (Lisbon, Portugal). This article is licensed under a Creative Commons Attribution 4.0 International License (CC BY).

\section{Introduction}

For several decades, Spain was one of the countries that stood out from European trends due to the absence of a relevant radical right party (Alonso \& Rovira Kaltwasser, 2015). However, between late 2018 and 2019, the radical right VOX (which means "voice" in Latin) very rapidly gained a significant electoral and institutional presence. Its organisational development has struggled to keep pace.

Because the radical right parties that first drew the attention of scholars, such as the French National Front, had charismatic leadership, some have considered them charismatic parties (Eatwell, 2018). In order to guarantee internal cohesion, charismatic parties tend to have weak organisation, a skeletal bureaucratic apparatus, and highly centralised decision-making that leads to low levels of institutionalization (Panebianco, 1988).
However, not all radical right parties have a charismatic origin (Eatwell, 2018).

Nonetheless, Panebianco's genetic model is a useful framework for analysing organisational development. This article examines VOX, a party that has developed through territorial penetration, directed by the central party leadership, and without external institutional sponsorship (such as from a union or confessional group) or charismatic leadership (Eliassen \& Svaasand, 1975; Panebianco, 1988). We refer to VOX simply as a radical right party, without the populist descriptor, which we explain below.

This article examines the extent to which VOX is striving to develop a mass party organization. According to the definition used in this thematic issue, a mass party organization is characterized by (a) the drive to recruit a large activist membership, (b) rootedness on the ground and the provision of a variety of activities to members 
(Albertazzi \& van Kessel, 2021), and (c) the preservation of "collective identities through ideology" (Panebianco, 1988 , p. 268) by creating closed political communities of activists, by promoting social integration among them and by shaping their interpretations of political developments (Albertazzi, 2016). We pay particular attention to VOX's territorial penetration, membership recruitment, the role of social media in creating collective identity and activists, and the degree to which decision-making in the party is centralised.

Many new parties have a political renewal agenda that encourages them to adopt a more participatory organisational model (Müller-Rommel, 1990), although this is not necessarily the case for populist radical right parties (Heinisch \& Mazzoleni, 2016). Yet, according to the notion of party lifespan (Pedersen, 1982), gaining political relevance often goes along with organisational change to guarantee centralised control in new parties (Bolleyer, 2013).

This article shows that VOX has taken early and uneven steps to build a mass organisation and initially opted for open membership recruitment with participatory organisational elements. Also, its rapid growth and quick entrance into political institutions at different state levels led the party leadership to establish more centralised control and limit members' prerogatives, though recruitment continued. Centralisation relates to organisational needs - given the party's quickly acquired political relevance-but also to the desire of the central party leadership to forestall the articulation of territorial interests or check them. The party's staunchly Spanish nationalist and state centralist ideology thus also affected its organisational choices. Today, VOX exhibits elements of mass party organisation and highly centralised decision-making in the hands of national party leaders in Madrid.

The article is organised as follows: The next section provides a brief history of the party. The third examines the steps it has taken to build a mass organisation. The fourth section analyses the progressive centralisation of decision-making and related internal conflict. A final section briefly concludes. The article draws on party documents, media coverage, interviews with five VOX leaders at the regional and national level (see Supplementary File), and the secondary literature.

\section{VOX: A Brief History}

This section outlines the origins of VOX, its ideology, and the rapid electoral rise that shaped its development.

VOX can be considered a radical right split from the Partido Popular (PP), Spain's main conservative party since the 1980s, in terms of its voter base and many of its founding leaders (Alonso \& Field, 2021; Barrio, 2020; Rama et al., 2021; Sangiao, 2018). VOX was founded in December 2013, in the midst of a severe economic and political crisis, which included far-reaching corruption scandals, particularly affecting the PP, and rising ten- sions surrounding Catalonia's political status. The party presented itself as the answer to the multiple overlapping crises. VOX denigrated the PP, under the leadership of Mariano Rajoy, for what it considered a feeble response to challenges to Spain's national identity and territorial integrity. Santiago Abascal, VOX's leader since 2014, refers to the PP as the "cowardly right" (derechita cobarde). The party took off electorally in the aftermath of the independence push in Catalonia, which culminated in a unilateral declaration of independence in October 2017 and the suspension of Catalonia's autonomy by the Rajoy government. The party has been relevant in Spanish politics since 2018.

VOX has much in common with populist radical right parties in Europe (Mudde, 2007, pp. 13-26), with national specificities. Yet, it is foremost a Spanish nationalist party that espouses and defends the unity of a single Spanish nation, patriotism, and Spanish symbols and cultural practices, such as bullfighting. It advocates for political re-centralisation of the Spanish state and shows particular disdain for Spain's own peripheral national identities and leaders in Catalonia, the Basque Country, and elsewhere. Thus, VOX's primary antagonists are "those 'threatening' their idea of Spain from the inside" (Marcos-Marne et al., 2021, p. 4). The first 10 measures in its 2018 manifesto, VOX's 100 Urgent Measures for Spain, come under the heading "Spain, Unity \& Sovereignty" (VOX, 2018), including the suspension of Catalonia's autonomy (measure no. 1), the banning of parties, associations, and nongovernmental organizations that seek to "destroy the territorial unity of the nation" (no. 2), the protection of national symbols (no. 3), and the establishment of a unitary state (no. 6). Indeed, support for the party in its 2018 electoral breakthrough in the region of Andalusia is linked to voter preferences on territorial issues (Turnbull-Dugarte, 2019a).

VOX also identifies external enemies and, similar to European populist radical right parties, is nativist and hostile toward Islam. The party explicitly links immigration to problems of law and order, and has accused unaccompanied migrant minors of being thieves and responsible for a wave of violence (VOX, 2020a). In the 2021 election for the Madrid regional parliament, the party hung a poster in the commuter train station that displayed an elderly, white woman and a hooded, masked, dark-skinned youth, with the false statement: "A MENA [a depreciative acronym for unaccompanied foreign minors] 4,700 Euros a month. Your grandmother 426-euro pension/month. VOX. Protect Madrid. Vote safe" (Blanco, 2021; authors' translation). VOX is less hostile to, and has at times shown support for, Latin American immigrants, whom the party portrays as more apt to assimilate because of linguistic and cultural ties (Sosa, 2018). While the party is clearly nativist, immigration has not been the party's core issue. In its 2018 manifesto of 100 urgent measures, those related to "Spain, Unity \& Sovereignty" appear before immigration measures (VOX, 2018). 
The party champions traditional, highly conservative values. It is resolutely antifeminist, putting centre-stage its opposition to "gender ideology" and the dismantling of what it refers to as feminist, LGBTQ, and other leftist "lobbies" (Bernardez-Rodal et al., 2020; Olivas Osuna \& Rama, 2021). In this way, it shares traits with Poland's Law and Justice Party. One of its signature policy priorities is to allow parents to require schools to ask for their express consent (pin parental/parental veto) before any school activity related to gender, feminism or sexual orientation. In contrast to some radical right parties that have moved to the centre on socio-economic issues (de Lange, 2007), VOX is neoliberal on socio-economic issues, stressing the reduction of taxes and the role of the state in the economy and social programs.

While there is wide scholarly consensus that VOX is a radical right party, disagreement remains about the degree to which the party was or is populist (e.g., Anduiza, 2018; Ferreira, 2019; Marcos-Marne et al., 2021; Olivas Osuna \& Rama, 2021). Using Mudde's (2007, p. 23) definition, populism is:

A thin-centered ideology that considers society to be ultimately separated into two homogeneous and antagonistic groups, "the pure people" versus "the corrupt elite," and which argues that politics should be an expression of the volonté générale (general will) of the people.

Populism, while present, was initially not prominent in the party's discourse (Anduiza, 2018; Ferreira, 2019; Marcos-Marne et al., 2021), though it may be on the rise (Olivas Osuna \& Rama, 2021).

Nonetheless, as a new, challenger party, political renewal and opposition to political insiders is clearly present (Barrio, in press). For example, in its 2018 manifesto, the party called for the reform of the electoral system, the elimination of candidate quotas (gender or otherwise) for elections, and the strengthening of legislation regarding incompatibilities for public officials once they leave office (VOX, 2018). The party's leaders frequently divide society into true Spaniards and traitors to Spain, or anti-Spaniards, harkening back to the rhetoric of the Franco dictatorship. However, this division does not neatly align with a corrupt elite/pure people distinction prominent in populism (see also Marcos-Marne et al., 2021). Given the ongoing scholarly debate, and because we do not independently measure populism, we refer to the party simply as radical right.

VOX does not explicitly advocate for an undemocratic political regime (Acha, 2019; Ferreira, 2019). However, it has attracted members with clear ties to organisations that are openly Francoist (Ramsay \& Provost, 2019) and it employs dog whistles in its discourse. For example, in 2020, Abascal accused the Sánchez government of being "the worst government in 80 years" (García, 2020), a timeframe that includes the Franco dictatorship. At the same time, it infuses its discourse with references to lib- eralism and freedom. It is staunchly authoritarian in its values, stressing law, order, and respect for authority.

VOX first presented candidates in the 2014 European parliament elections, winning only $1.6 \%$ of the vote and no seats. It performed poorly in national parliamentary elections in 2015 and 2016 (0.2\% in each). This was when Podemos and Ciudadanos (Cs) broke the dominance of the Partido Socialista Obrero Español (PSOE) and PP in Spain's national party system.

In December 2018, VOX achieved a surprise breakthrough in the regional elections in Andalusia, Spain's most populous region (Turnbull-Dugarte, 2019a). This was the first election outside of Catalonia since the independence push there. VOX won nearly $11 \%$ of the vote and seats in the fragmented parliament. Subsequently, it supported a right-wing minority government of the PP and Cs. A few months later, in April 2019, VOX won $10 \%$ of the vote in Spain's parliamentary elections and entered parliament with $7 \%$ of the seats.

Parliament failed to form a government. In new elections in November 2019, VOX won 15\% of the vote, making it the third largest party in parliament with $15 \%$ of the seats. The party closed in on the PP $(21 \%)$ and surpassed previous newcomers Cs (7\%) and Unidas Podemos (UP; 13\%).

In between, in May 2019, Spain held European, local, and regional elections in 12 regions, with VOX winning seats in seven regional parliaments (the party had also won representation in the region of Valencia back in April). In this period, VOX supported PP-Cs governments in the Madrid and Murcia regions and in the City of Madrid, won 529 seats in local parliaments, and entered the European parliament with three seats. In the 2020 Basque and Galician elections, where peripheral national identities are more prominent, it only gained one seat in the Basque parliament. Yet, in 2021, it entered the Catalan parliament with $8 \%$ of the seats, overtaking PP and Cs.

Based on the April 2019 national elections, VOX supporters tended to be at the higher end of the income and education scales and urban residents, unlike many European populist radical right voters (Turnbull-Dugarte et al., 2020). Men, right wing political ideology, church attendance, and dissatisfaction with democracy are positively associated with voting for VOX. The most important predictor of a vote for VOX was a strong attachment to Spanish national identity combined with a negative evaluation of the existing political situation.

Having provided this short history, we examine the party's efforts to build a mass organisation between 2014 and 2020.

\section{Steps Toward Building a Mass-Party Organisation}

Despite being a new party, VOX is not innovative in its organisation. It has adopted a model, in nascent form, comparable to that of mass parties. As conceptualized in the introduction to this thematic issue, mass 
parties exhibit the drive to recruit a large activist membership, rootedness on the ground and the provision of a variety of activities to members, and the preservation of collective identities through ideology (Albertazzi \& van Kessel, 2021).

Uneven recruitment and weak organisation characterized VOX's initial years. While the party made efforts to develop its organisation, electoral growth outpaced organisational development. This section examines (a) the degree of party organisation, paying particular attention to territorial penetration, (b) membership recruitment, and (c) the role of social media in creating collective identity and activists.

\subsection{Territorial Penetration and Rootedness on the Ground}

From its founding, VOX aspired to develop a full-fledged party organisation and organised according to the branch model with a clear predominance of vertical links between branches and the central party. The party established local, provincial, and national branches. It has been extending its reach throughout the territory, especially since accessing Spain's political institutions in late 2018-2019. It is present in all provinces, though unevenly. In accordance with the territorial penetration model (Eliassen \& Svaasand, 1975), the centre directed its development-to the point that the national leadership has often appointed the subnational executives. Provincial branches only have a right to designate their own leadership if they have over 500 members. Candidates to the provincial executive posts need the formal backing of at least $10 \%$ of the provincial fee-paying party members to be able to register as candidates.

Contrary to Duverger's (1954) expectation, the party's territorial articulation does not reflect the administrative structure of the state in that there are no regional (autonomous community) branches. Instead, the party has national, provincial, and local branches. Provinces are administrative units that are typically smaller and less powerful than the autonomous communities are. This is, in large part, because of VOX's ideological opposition to political decentralisation. The two main state-wide parties, PP and PSOE, adjust policy positions and salience to the regional context, thereby generating a certain level of cross-regional variation. VOX, by contrast, insists that its message is uniform. According to one VOX leader: "Even the internal organisation of the party is designed so that the same is said throughout Spain" (Interview no. 5).

This is an anomaly in multilevel political systems including Spain, where all state-wide parties have regional branches. The existence of regional branches favours the development of territorial interests within parties, a source of tension between the centre and the periphery. At the same time, it forces parties to balance regional power within them. Thus, VOX's decision is also a deliberate attempt to build a highly centralised organisation with a unitary model of vertical integration (Thorlakson, 2009), and to block incentives for articulating regional interests.

The highest executive body is the National Executive Committee (NEC). The General Assembly elects the NEC using a closed list ballot(s). It has only 12 members (including the president, three vice presidents, general secretary, and treasurer), assisted by 13 vice secretariats, who are not part of it. The founders' territorial concerns are also reflected in its design

The provincial presidents are not on the [National] Executive Committee because we do not want the provincial presidents to influence a decision in favour of their provinces....We very much insist on that; we do not want to be a federal party like other parties. (Interview no. 3)

The main individual offices are the President, who has the highest executive and representative powers, and the Secretary General, who carries out organisational functions. The NEC is clearly the dominant party body. According to one VOX leader:

In VOX, the truth is that we are very close because we are also all good friends; no, but there is an Executive Committee that we call the centre. Any decision on an agreement, any decision on the program, any decision on territorial organisation goes to the executive committee, which sometimes meets once a week, sometimes every fifteen days. (Interview no. 3)

The General Assembly is, formally, the highest body of the party. It comprises all party members. There is no broader decision-making body than the NEC between General Assemblies, since the Political Council that the General Assembly elects only has advisory functions. Party staff remained at a bare minimum of five or six until 2018 ("VOX refuerza su estructura," 2019). In 2018, VOX employed 16 people, which increased to 34 in 2019 (Torres, 2020).

Along with building structures on the ground, the party has sought to recruit an activist membership, to which we turn.

\subsection{Member Recruitment}

The day of its public debut in January 2014, VOX called on Spanish voters to join the party's ranks. The intention to build a mass party becomes apparent when one considers how simple joining the party was, according to its 2014 statutes. It only required paying a monthly fee and signing the party's foundational manifesto. Recruitment led to ideological heterogeneity, as it afforded little control to party leaders over whom joined the party, and for what purpose. Like many new parties, VOX also initially offered members participation in internal decisions, in particular the selection of internal officers 
and candidates for public office through party elections. However, formally and in practice, internal democracy would decline over time.

In the early years, volunteers carried out everyday party functions. Party members held several organisational positions simultaneously and even provided funds to organise party events (Segurola, 2014). When its big electoral leap took place in 2018-2019, these party members added elected office to their other posts. This contributed to a de facto, if not de jure, concentration of power around some individuals across all organisational levels. One reason for recruiting members was to help finance the party's operations, since the party had no access to public funds. Public funding after 2018 would also facilitate organisational development. The party received EUR 4,160,056 in public funding in 2019 and EUR 9,865,450 in 2020 (VOX, 2021), though the party supports ending public subsidies for political parties and unions (VOX, 2020b). The proportion of public funding increased from zero in 2018 to $61 \%$ in 2019 and $66 \%$ in 2020.

VOX's membership and electoral growth had more to do with political events than specific party actions. By 2016, the party had approximately 3,000 members. This increased significantly in the aftermath of the failed secession attempt by the Catalan independence movement in the fall of 2017 (Barrio, 2020). The second leap occurred after the censure motion in June 2018 against the PP government of Prime Minister Mariano Rajoy that brought Prime Minister Pedro Sánchez and PSOE to government. According to VOX's data, it reached more than 20,000 members in 2018 (see Table 1). Another jump occurred after VOX's electoral success in December 2018 in Andalusia. The party reported exceeding 36,000 members in March 2019, and 52,000 after the November 2019 general elections. After the failed censure motion in October 2020, lodged by VOX against Prime Minister Sánchez and the PSOE-UP coalition, the party claimed it had more than 60,000 members (Barrio, in press).

Table 1. VOX party members.

\begin{tabular}{lr}
\hline Year & Members \\
\hline 2017 & 4,951 \\
2018 & 20,500 \\
2019 & 56,786 \\
2020 & 62,347 \\
\hline
\end{tabular}

Source: Data for 2017 from Ballesteros (2018); data for 2018 from Valls (2018); data for 2019 from Valls (2020); data for 2020 from "VOX recibió" (2021).

In its March 2020 statutes, and due to the organisation's rapid growth, VOX made some changes concerning new joiners. For instance, it established a provisional period of nine months during which new affiliates would have limited rights (new members were allowed to vote in internal processes but not eligible to be candidates for office). The NEC can also deny full membership to people-also an indication of progressive centralisation of decision-making. At the same time, the party introduced the status of "sympathizer" to bring in those who collaborate with the party's activities or contribute financially without being members: This offers a laxer connection to the party that many other parties also use to promote societal penetration.

Recruitment has been geographically uneven from the beginning. Party building gathered momentum in the aftermath of the first party primaries to elect the national leadership in July 2014. In September and October 2014, the party established Provincial Executive Committees (PECs), also through internal elections. PECs formed in only 15 out of 52 Spanish provinces, since VOX had few members and no grass-roots territorial organisations on which to rely. At the end of 2014, Madrid and Valencia were strongholds in terms of members and structure. Six years later, Murcia and Andalusia have also become organisational bastions.

VOX's initial open recruitment model attracted a heterogeneous group of people to the party. Two elements were however common to most new members: they had no previous political experience and volunteered their free time to the party (Interviews no. 2 and no. 4). When presenting a plan for party reorganisation at the 2019 General Assembly, Javier Ortega Smith, the party's General Secretary, admitted that pre-2019 VoX was an "amateur" party and that its cadres lacked "training" (“VOX refuerza su estructura," 2019).

VOX's model for organising members is exclusively territorial and, unlike many new parties, it does not have virtual groups, though it makes extensive use of social networks. Formally, it does not have a sectoral structure and has not developed affiliated mass organisations. The only exception is Solidaridad, the union formed in 2020.

Nonetheless, it has close relationships with some organised interests, including pro Hunting, Fishing and Bullfighting groups, such as the Asociación Internacional de Tauromaquia (International Bullfighting Association), and ultra-conservative, anti-abortion rights, anti-feminist and other groups that feel aggrieved by progressive gender and LGBTQ policies. For example, during the March 2021 regional election campaign in Madrid, VoX committed to a 6-point set of demands of the ultra-conservative Catholic organisation Hazte Oír (which translates to "make yourself be heard"). The demands included "promoting the right to life from conception to natural death," the legalization of the parental veto, the repeal of progressive LGBTQ and Transgender Laws, and the defence of Christian symbols (González, 2021; Hazte Oír, 2021).

The origins of the party are closely linked to ETA (Basque Homeland and Freedom) victims' associations and other organisations active in the fight against ETA. ETA is a now disbanded Basque independence terrorist organisation. Two of VOX's founders were victims of ETA. These associations include the Asociación 
de Víctimas del Terrorismo (Association of Victims of Terrorism), Fundación Valores y Sociedad (Values and Society Foundation), and Fundación Villacisneros (Villacisneros Foundation). In September 2020, VOX established its own think-tank, Fundación Disenso (Dissent Foundation).

Given the party's nascent organisational development, social media has played an important role in building the party, to which we now turn.

\subsection{Social Media and Party Building}

Once an obscure party desperate for attention from the mainstream media, VOX learned to make a direct connection to potential supporters. The internet, social media, and applications such as Whatsapp and Telegram have been essential for forging a collective identity and recruiting and mobilising activists.

The party attributes some of its initial success to social media (Ballesteros, 2020). For example, during the electoral campaign in Andalusia, the party disseminated a video of Abascal riding a horse in the countryside with other men and captioned it: "The re-conquest will begin in Andalusian territory." It was shared over a million times. After experiencing electoral success in Andalusia, the party learned that sharp criticism of, and an adversarial relationship with, the mainstream media (in Trumplike fashion) would generate additional attention for its activities (Ramírez, 2020). According to VOX's communication director: "We don't need big media. They give you prestige, but to reach the public that interests us and that lives on their mobile phone, [internet] networks are enough for us. In the US, Trump won without the support of the traditional media" (Negre, 2018).

In mid-2021 (see Figure 1), vOX had the most followers of Spain's national parties on Instagram, which the party strategically prioritized alongside Facebook. VOX took interest in Instagram because of the youth of its users (Bernardez-Rodal et al., 2020, p. 3). VOX also has the most subscribers on YouTube $(431,000$ compared to Podemos' 125,000$)$ and members on Telegram $(53,500$ compared to Podemos' 29,752). However, the left wing Podemos leads, by far, on Twitter and Facebook.

VOX had "greater visibility and impact on social networks" than Spain's other national parties in a study in late 2019, a non-electoral period (Cea Esteruelas, 2019, p. 41). It achieved greater interaction and engagement on the four most used social networks (Facebook, Twitter,

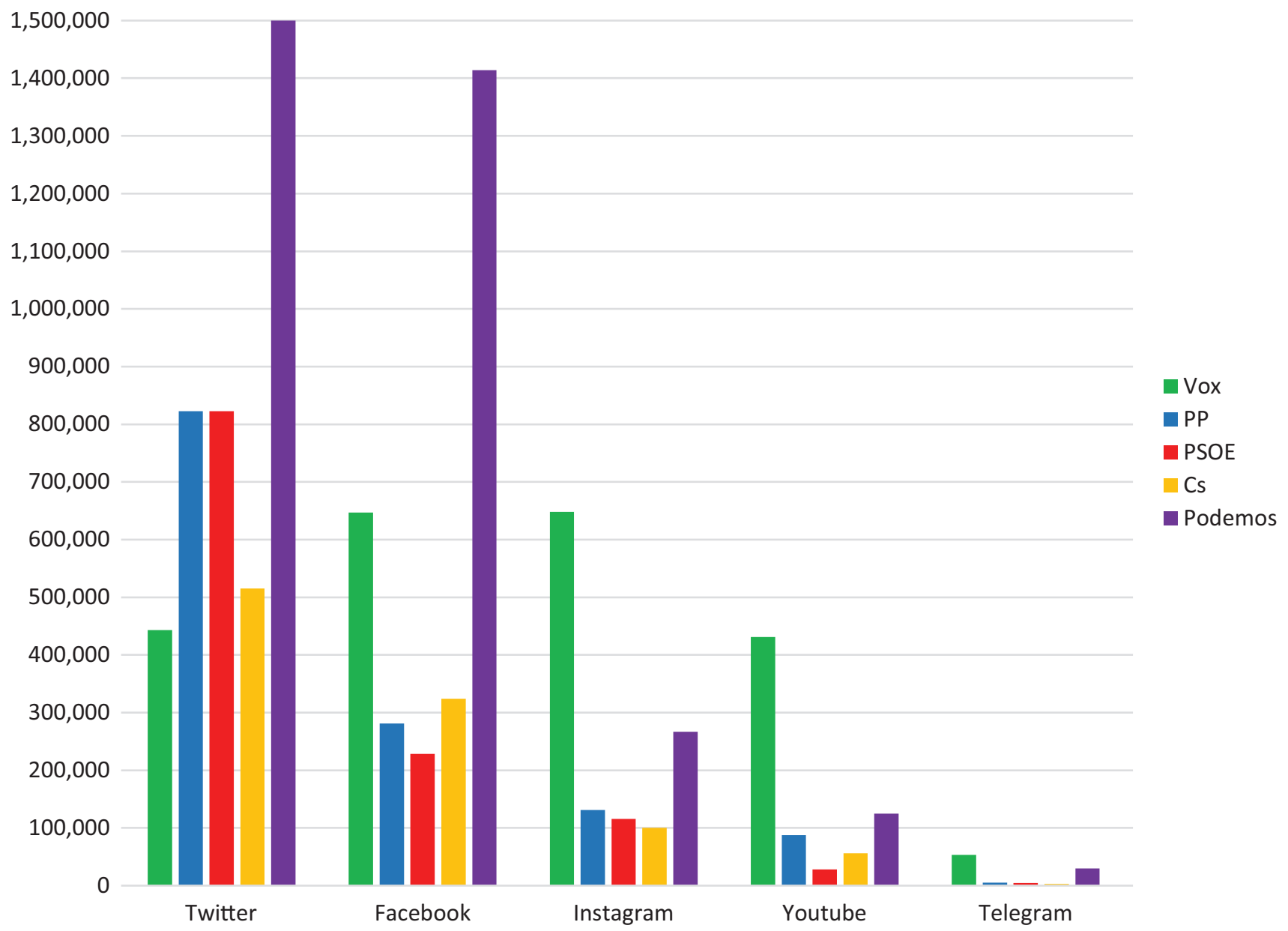

Figure 1. Social media followers. Notes: Followers (Twitter, Facebook, Instagram), subscribers (YouTube), and members (Telegram); rounded, as some platforms only list rounded numbers. 
YouTube, and Instagram). Additionally, by the end of the April 2019 election campaign, VOX had attained the greatest "share of voice," a metric for visibility (Dusster, 2019). This is perhaps not surprising given VoX's new party status. A prior study found that previous newcomers, Podemos and Cs, received more likes and higher engagement on Instagram in the 2015 and 2016 elections (Turnbull-Dugarte, 2019b).

A study of the content of VOX's Instagram posts prior to the April 2019 general elections shows that 56\% relate to a "danger-enemy dimension," which includes the left, separatist nationalism, feminism, and Islam, immigration and women (Aladro Vico \& Requeijo Rey, 2020 , p. 211). Another study of Instagram posts finds that VOX employs "Manichean-type contrasts such as 'us/them,' 'good/evil...'" (Bernardez-Rodal et al., 2020, p. 9). The first study concludes that VOX's posts aim to recruit activists: "The discourse is that of a civil resistance movement" (Aladro Vico \& Requeijo Rey, 2020, p. 221). According to Bernardez-Rodal et al. (2020, p. 3), VOX's social media strategy was designed, in part, by Trump associate Steve Bannon, who appeals to basic emotions and seeks to construct a "closed group identity built around the feeling of loss of traditional values."

On Facebook, VOX pays for its content to reach potential supporters and its opponents on the left and extreme left, in hopes of provoking them to maximize diffusion (Méndez \& Villarino, 2018). Social media is also key to their mobilisation strategy. According to VOX's social media guru, now vice secretary of communication: "We are a machine for mobilizing people for our events" (Negre, 2018).

The degree to which social media brings VoX electoral and other dividends remains to be determined, especially because the party also now receives a great deal of attention from traditional media and more coverage than a comparable party prior to the 2019 Andalusian election, its electoral breakthrough (Olalla et al., 2019). However, studies of the $15 \mathrm{M}$ indignados movement of 2011 in Spain demonstrate social media's ability to mobilize massive protests and bring out new participants, in that case without the attention of traditional media or organisations such as political parties and unions (Anduiza et al., 2014). Furthermore, comparative studies indicate that online contact via social networks is important for mobilizing younger voters (Aldrich et al., 2016).

\subsection{Why Grow an Active Base of Members?}

Initially, the party sought to recruit members to fund and organize party activities at a time when the party attracted little attention from the media and had no public funding. Members staffed and at times paid for party events (Segurola, 2014), and they helped get the word out. With growing public attention, the party also had to field candidates across the Spanish territory. Its adversarial relationship with the media likely reinforces the recruitment of an activist membership base, though, once it entered Spain's political institutions, VOX became more careful about whom it recruited (Interview no. 5). A larger pool of activists also allowed VOX to organize rallies across the Spanish territory. These events bring the party attention and the opportunity to claim to represent the "real" Spain. As Casals (2021) suggests, VOX carries the "re-conquest" narrative to the streets, where, like on social media, it can make the symbolic and emotional appeals it prefers.

Thus, VOX has taken the first steps toward the development of a mass-party-like organisation by expanding its territorial presence, recruiting members and activists and creating collective identity. This has gone along with the centralisation of power, which we now discuss.

\section{Internal Democracy, Centralisation, and Territorial Conflict}

While challenges related to and limits on internal democracy were present from the start, VOX has experienced progressive centralisation of decision-making authority by and in the hands of the national leadership, particularly since entering the political institutions in 2018-2019. Organisational change in this direction is in accord with Pedersen's (1982) notion of party lifespan. When parties gain relevance, they reduce internal democracy. Additionally, it is due to the party's opposition to Spain's political regions.

The party's initial open recruitment model and rapid growth produced internal heterogeneity. The leadership's efforts to centralise have both responded to and provoked internal disputes and factionalism. As we discuss below, many conflicts resulted from limits the party national executive imposed on territorial branch autonomy. Despite the fact that regional branches do not formally exist, once there is a regional political arena and representation is obtained, regional interests arise that may conflict with the national leadership.

Unlike some radical right parties, VOX is not synonymous with a charismatic leader. Its leadership is best characterised as oligarchic. One can easily imagine the survival of VOX without Abascal. He is, of course, a powerful and significant person among the leaders (formally and informally) participating in the making the most important decisions-including Javier Ortega Smith, Iván Espinosa de los Monteros, and Rocío Monasterio (illustrating the closeness of the leadership, the latter two are a couple). Some belong to the NEC, while others, like Espinosa and Monasterio, do not. In March 2020, the party also established a new body, called the Political and Institutional Strategy Committee, on which they all serve, along with two additional members.

Like many new parties, VOX initially allowed some member participation in internal decisions. In part, this was spurred by Spanish legislation. Spain's party legislation requires political parties to have internal party democracy. VOX's first attempt to register the party in 
late 2013 with the Ministry of Interior was rejected because some clauses in the party's proposed statutes did not allow for sufficient internal discussion and participation by the rank-and-file. The party had to modify the statutes, in particular regarding the functioning of its General Assembly (López-Fonseca, 2014). Thus, VOX's first draft statutes were also designed to give the national leadership some control over internal processes.

The party's statutes, approved by the first General Assembly in July 2014, established the bi-annual party congresses, opened to all party members. They also stipulated the selection of internal party positions and candidates for public office via party elections, which is not a legal requirement. However, there was one caveat. Provincial and municipal party organisations with fewer than 500 party affiliates could select the candidates without an electoral process, if the candidate or list had the support of a simple majority of party members and was vetted by the national leadership.

Electoral success in the December 2018 Andalusian elections marked a milestone in VOX's development, and a reduction in internal party democracy followed. The General Assembly held in February 2019 limited the use of party elections to internal party positions. The selection of candidates for public office came to depend on the subnational executives, who were responsible for bringing their proposals to the NEC for approval, except for the general and European elections. For these, the NEC chooses the candidates and only needs to "consult" with the PECs.

In the context of Covid-19 pandemic restrictions, critics of VOX's national leadership, organized as the group VoxHabla, were not permitted to participate in the March 2020 General Assembly, which was only open to party and public office holders. The Assembly elected Abascal and his team for another four years. The party's Electoral Committee rejected the candidacy of Carmelo González, leader of VoxHabla, and his alternative list because they lacked sufficient formal backing. The Assembly approved several changes to the party statutes, which further reduced internal democracy. For example, the NEC can now send compulsory instructions to other party bodies and disband subnational executives that do not abide by them and replace them with interim managing committees (gestoras), with agreement of two-thirds of the NEC. According to the previous statutes, the NEC could only dissolve the subnational committees if its president or a majority of its members stepped down.

These changes give the NEC more control over the selection of party cadres at the provincial and local levels. The central party leadership is thus attempting to retain control of a party that experienced rapid growth and relevance with a heterogeneous and largely inexperienced membership. Begoña Conde, vice secretary of member training stated that the party should work like an "orchestra: discipline, training and the same score" ("Abascal sale reforzado," 2020). Tomás Fernández, vice secretary of organisation, summarized the changes as "integration and homogenization" ("Abascal sale reforzado," 2020).

The leadership's efforts to centralise provoked internal disputes about the lack of transparency and internal democracy, such as with VoxHabla. Several splits from the party have also occurred that criticise the centralisation of power in the hands of Abascal and the ruling clique, including TúPatria, España Suma, and Valores.

As a consequence of VOX's remarkable growth between 2018 and 2020, a series of crises emerged at all levels of the party organisation. The national leadership and different groups within the provincial-and to a lesser degree-local executives vied for control over (a) finances, (b) the vetting of electoral lists, (c) organic positions inside the party, and (d) government-formation negotiations. In the years 2019 and 2020, we identified 15 such major provincial crises (Albacete, Asturias, Almería, Baleares, Cádiz, Cantabria, Granada, Jaén, León, Murcia, Sevilla, Toledo, Valencia, Valladolid, and Zamora) and five municipal crises (Algeciras, Badajoz, Málaga, Toledo, Melilla). Exceptionally, the crises erupted over disagreements encompassing all four elements, as in the case of Murcia beginning in the spring of 2019. The attempt by party founders to forestall the entrenchment of regional interests by skipping the autonomous communities (regions) in the party's structure only moved the focus one level down, to the PECs. Several conflicts gained media attention and an avalanche of denunciations ended up in Spanish courts.

Since 2019, candidate selection for party lists for regional and local elections is, in theory, the prerogative of the provincial and municipal executives. However, the lists made by PECs must go to the NEC for vetting and approval. This has generated conflict between the national leadership who wants to have the final say on the lists and the provincial leadership who resents this, and between the provincial leadership and adversarial provincial groups who want to take the reins of the party organisation. Examples of this type of conflict occurred across the whole country. The NEC and, more concretely, Abascal and Ortega Smith (president and general secretary, respectively), used the infighting within the subnational organisations to force the dissolution of provincial and municipal executives and set up interim caretaker executives (gestoras), controlled from Madrid.

Internal party elections have been another major source of conflict. Procedural irregularities tainted many provincial and national party elections. For example, incumbent candidates were able to use the party apparatus to their advantage and alternative candidacies were discouraged. Several of the party's internal elections between 2018 and 2020 were challenged in court by disgruntled rank-and-file party members or by unsuccessful candidates, such as in Granada, Seville, and Valencia in 2020. The critical platform VoxHabla was established precisely with the objective of denouncing the irregularities of internal party elections in 2020. The national leadership agreed to repeat party elections in Malaga, 
Alicante, and Jaen due to irregularities. Revealing the concerns of the party leadership, Abascal expressed that he is "worried" party elections "have generated divisions and conflict in some provinces" and wondered if it would not be better to "suspend this type of provincial elections because they generate a lot of uncertainty and infighting" (González, 2020).

Party finance has been the third major arena of infighting. Provincial party organisations have their own bank accounts, where they receive public funds and members' fees and donations. But these accounts are managed by the national leadership, leaving no financial autonomy to provincial leaders. In some cases, this pushed provincial leaders to create parallel accounts, a practice which members of the provincial leadership or rank-and-file have challenged legally, for example in Murcia and Valencia.

Thus, the central leadership's efforts to centralise have both responded to and provoked internal disputes and factionalism. The end result of this tug of war between the national leadership and the provincial and local branches has been the weakening of the party's internal democracy and the concentration of power in the hands of the NEC.

\section{Conclusion}

A young party that first gained representation in late 2018 , VOX rapidly became politically relevant at all state levels. Despite being a new party, VOX did not choose a novel organisational format. It adopted the structure of mass parties albeit in embryonic form. VOX strove to achieve rootedness on the ground via territorial penetration, to recruit a large activist membership base, and to create collective identity, including through the use of social networks, with significant control retained by the central party leadership.

VOX initially adopted an open recruitment model and provided members with input into the selection of party officers and candidates. Also, the national leadership has progressively concentrated decision-making authority in its hands, particularly since entering the political institutions. Centralisation in part responds to organisational needs, as Michels (1962) discovered. VOX is not unusual in doing so-new parties commonly confront a tension between the desire of the founding core to maintain its position and influence, and the need to develop a viable organisational structure (Bolleyer, 2013). Nevertheless, organisational choices were also the result of the central party leadership's desire to forestall the articulation of territorial interests, given the party's Spanish nationalist and state centralist ideology. Efforts to centralise have both resulted from, and in turn provoked, several internal disputes.

A few aspects of the party stand out. The first is the degree to which it articulates its nationalism in opposition to Spain's own peripheral national identities and in favour of a centralised state. This has led to a party struc- ture, which, unusually, does not conform to the structure of the state. This organisational mismatch is likely to continue to present challenges to the party, given the reality of Spain's autonomous communities. Relatedly, the party may face the dilemma of whether to adapt its pitch, including in which language, to Spain's distinct historical communities in order to grow in places such as Catalonia and Galicia. VOX also stands out due to its staunch neoliberal economic positions. It remains to be seen whether the party will adapt its economic positions in an attempt to appeal to more voters. Finally, the party is ultra conservative, with strong ties to anti-feminist and anti-LGBTQ groups.

Much remains unknown about VOX's organisation, particularly about its members and activists. Future research that draws on participant observation techniques and/or surveys of activists, providing windows into the party, would be particularly beneficial.

\section{Acknowledgments}

This research was partly funded by the Qatar Foundation/GUQ-sponsored Faculty Research Grant. All authors contributed equally to the study. Authors are listed in reverse academic rank order.

\section{Conflict of Interests}

The authors declare no conflict of interests.

\section{Supplementary Material}

Supplementary material for this article is available online in the format provided by the author (unedited).

\section{References}

Abascal sale reforzado como líder indiscutible de Vox en su "Vistalegre III" [Abascal is reinforced as the undisputed leader of VOX in its "Vistalegre III"]. (2020, March 7). RTVE. https://www.rtve.es/noticias/ 20200307/vox-pide-funcionar-como-orquestapara-lograr-objetivo-gobernar-para-transformarespana/2006780.shtml

Acha, B. (2019, January 6). No, no es un partido (neo)fascista [No, it is not a (neo)fascist party]. Agenda Pública. https://agendapublica.es/no-no-esun-partido-neofascista

Aladro Vico, E., \& Requeijo Rey, P. (2020). Discurso, estrategias e interacciones de VOX en su cuenta oficial de Instagram en las elecciones del 28-A. Derecha radical y redes sociales [VOX's speech, strategies, and interactions on its official Instagram account in the 28-A elections. Radical right and social networks]. Revista Latina de Comunicación Social, 77, 203-229.

Albertazzi, D. (2016). Going, going,... not quite gone yet? 'Bossi's Lega' and the survival of the mass party. Contemporary Italian Politics, 8(2), 115-130. https:// 
doi.org/ 10.1080/23248823.2016.1193349

Albertazzi, D., \& van Kessel, S. (2021). Right-wing populist party organisation across Europe: The survival of the mass party? Introduction to the thematic issue. Politics and Governance, 9(4), 224-227.

Aldrich, J. H., Gibson, R. K., Cantijoch, M., \& Konitzer, T. (2016). Getting out the vote in the social media era. Are digital tools changing the extent, nature and impact of party contacting in elections? Party Politics, 22(2), 165-178.

Alonso, S., \& Field, B. N. (2021). Spain. The development and decline of the Popular Party. In T. Bale \& C. Rovira Kaltwasser (Eds.), Riding the populist wave: Europe's mainstream right in crisis (pp. 216-245). Cambridge University Press.

Alonso, S., \& Rovira Kaltwasser, C. (2015). Spain: No country for the populist radical right? South European Society and Politics, 20(1), 21-45.

Anduiza, E. (2018, December 6). El discurso de VOX [VOX's discourse]. Agenda Pública. https://agenda publica.es/el-discurso-de-vox

Anduiza, E., Cristancho, C., \& Sabucedo, J. M. (2014). Mobilization through online social networks: The Political protest of the indignados in Spain. Information, Communication \& Society, 17(6), 750-764.

Ballesteros, R. (2018, December 15). De 4.951 a 20.706: VoX cuadruplica su número de afiliados en solo un año [VOX quadruples its number of affiliates in just one year]. El Confidencial. https://www. elconfidencial.com/espana/2018-12-15/de-4-951-a20-706-vox-cuadruplica-su-numero-de-afiliados-ensolo-un-ano_1704750

Ballesteros, R. (2020, February 8). Twitter, Instagram, YouTube... VOX arrasa en las redes tras el $10 \mathrm{~N}$ y la crisis catalana [Twitter, Instagram, YouTube... VOX sweeps the networks after $10 \mathrm{~N}$ and the Catalan crisis]. El Confidencial. https://www.elconfidencial. com/espana/2020-02-08/twitter-instagram-

afiliacion-la-subida-mas-fuerte-de-vox-desde-sunacimiento_2411623

Barrio, A. (2020). VOX, la fin de l'exception espagnole [VOX, the end of the Spanish exception]. In Innovation Politique 2019 (Tome 1, pp. 169-194). Fondation pour l'Innovation Politique.

Barrio, A. (in press). VOX and the irruption of the radical right in Spain. In O. Barberà (Ed.), The new radical right in Southern Europe. Coppieters Foundation.

Bernardez-Rodal, A., Requeijo Rey, P., \& Franco, Y. G. (2020). Radical right parties and anti-feminist speech on Instagram: VOX and the 2019 Spanish general election. Party Politics. Advance online publication. https://doi.org/10.1177\%2F1354068820968839

Blanco, P. R. (2021, April 21). VOX miente sobre los 4.700 euros que Madrid paga por menor extranjero no acompañado [Vox lies about the 4,700 euros Madrid pays per unaccompanied foreign minor]. EI País. https://elpais.com/elpais/2021/04/21/hechos/ 1619007080_623729.html
Bolleyer, N. (2013). New parties in old party systems: Persistence and decline in seventeen democracies. Oxford University Press.

Casals, X. (2021, April 12). VOX entra en campaña [VOX enters the campaign]. Agenda Pública. https:// agendapublica.es/vox-entra-en-campana-larecuperacion-de-la-plaza-roja

Cea Esteruelas, M. N. (2019). Nivel de interacción de la comunicación de los partidos políticos españoles en redes sociales [Level of interaction of the communication of Spanish political parties in social networks]. Marco, 5, 41-57.

de Lange, S. L. (2007). A new winning formula? The programmatic appeal of the radical right. Party Politics, 13(4), 411-435.

Dusster, D. (2019, May 8). Más 'likes' que votos para VOX [More 'likes' than votes for VOX]. La Vanguardia. https://www.lavanguardia.com/politica/ 20190508/462114377282/vox-impacto-redessociales-resultados-electorales.html

Duverger, M. (1954). Political parties: Their organization and activity in the modern state. Meuthen.

Eatwell, R. (2018). Charisma and the radical right. In J. Rydgren (Ed.), The Oxford handbook of the radical right (pp. 251-268). Oxford University Press.

Eliassen, K. A., \& Svaasand, L. (1975). The formation of mass political organizations: An analytical framework. Scandinavian Political Studies, 10(A10), 95-121.

Ferreira, C. (2019). VOX como representante de la derecha radical en España: Un estudio sobre su ideología [VOX as a representative of the radical right in Spain: A study about its ideology]. Revista Española de Ciencia Política, 51, 73-98.

García, L. B. (2020, September 10). Abascal en TVE: "Estamos ante el peor gobierno en 80 años y ustedes actúan como el NODO" [Abascal on TVE: "We are facing the worst government in 80 years and you act as the NODO"]. La Vanguardia. https://www. lavanguardia.com/politica/20200910/483392790 109/santiago-abascal-tve-peor-gobierno-90-anosnodo.html

González, M. (2020, October 5). VOX se plantea suprimir las elecciones internas ante las denuncias de fraude [VOX plans to suppress internal elections due to fraud complaints]. El País. https://elpais.com/ espana/2020-10-05/vox-se-plantea-suprimirlas-elecciones-internas-ante-las-denuncias-defraude.html

González, M. (2021, April 29). Far right Vox commits to blocking access to abortion and euthanasia in Madrid. El País. https://english.elpais.com/politics/ 2021-04-29/far-right-vox-commits-to-blockingaccess-to-abortion-and-euthanasia-in-madrid.html

Hazte Oír. (2021, April 19). Seis cuestiones decisivas para el 4-M [Six decisive questions for 4-M].

Heinisch, R., \& Mazzoleni, O. (2016). Understanding populist party organization. Palgrave Macmillan.

López-Fonseca, Ó. (2014, January 22). Interior retrasó 
un mes la legalización de VOX porque no cumplía la Ley de Partidos [Interior delayed the legalization of VOX for a month because it did not comply with the Party Law]. Vozpópuli. https://www.vozpopuli.com/ espana/Vox-Ministerio_del_Interior-Ley_de_ Partidos_0_663533674.html

Marcos-Marne, H., Plaza-Colodro, C., \& O’Flynn, C. (2021). Populism and new radical-right parties: The case of VOX. Politics. https://doi.org/10.1177\% 2F02633957211019587

Méndez, M. Á., \& Villarino, Á. (2018, December 20). La maquinaria de VOX en Facebook: Así pagan para indignar a la izquierda y viralizarse [The VOX machinery on Facebook: This is how they pay to outrage the left and go viral]. El Confidencial. https://www. elconfidencial.com/tecnologia/2018-12-20/voxfacebook-redes-sociales-pablo-iglesias-477_ 1713790

Michels, R. (1962). Political parties: A sociological study of the oligarchical tendencies of modern democracy. The Free Press.

Mudde, C. (2007). Populist radical right parties in Europe. Cambridge University Press.

Müller-Rommel, F. (1990). New political movements and 'new politics' parties in Western Europe. In R. J. Dalton \& M. Kuechler (Eds.), Challenging political order: New social and political movements in Western Democracies (pp. 209-31). Polity Press.

Negre, J. (2018, December 9). El joven propagandista de VOX que montó a Abascal en un caballo [The young VOX propagandist who rode Abascal on a horse]. El Mundo. https://www.elmundo.es/cronica/2018/ 12/09/5c0a9d12fdddff0e388b4606.html

Olalla, S., Chueca, E., \& Padilla, J. (2019, January 10). Spain is no longer exceptional: Mainstream media and the far-right party VOX. LSE: Euro Crisis in the Press. https://blogs.lse.ac.uk/eurocrisispress/2019/ 01/10/spain-is-no-longer-exceptional-mainstreammedia-and-the-far-right-party-vox

Olivas Osuna, J. J., \& Rama, J. (2021). Covid-19: A political virus? VOX's populist discourse in times of crisis. Frontiers in Political Science, 3. https://doi.org/10.3389/ fpos.2021.678526

Panebianco, A. (1988). Political parties: Organization and power. Cambridge University Press.

Pedersen, M. N. (1982). Towards a new typology of party lifespans and minor parties. Scandinavian Political Studies, 1(5), 1-16.

Rama, J., Zanotti, L., Turnbull-Dugarte, S., \& Santana, A. (2021). VOX: The rise of the Spanish populist radical right. Routledge.

Ramírez, D. (2020, April 19). "Nos funciona, enardece a los nuestros": La calculada estrategia de VOX en su guerra con los medios ["It works for us, it fires up our own": VOX's calculated strategy in its war with the media]. El Español. https://www.elespanol.com/ espana/politica/20200419/funciona-enardececalculada-estrategia-vox-guerra-medios/ 483203061_0.html

Ramsay, A., \& Provost, C. (2019, April 25). Revealed: The Trump-linked 'super pac' working behind the scenes to drive Europe's voters to the far right. OpenDemocracy. https://www.opendemocracy.net/en/5050/ revealed-the-trump-linked-super-pac-workingbehind-the-scenes-to-drive-europes-voters-to-thefar-right

Sangiao, S. (2018, November 28). Los orígenes de VOX: El Aznarato y la lucha contra ETA [The origins of VOX: The Aznarato and the fight against ETA]. Contexto $y$ Acción. https://ctxt.es/es/20181129/Politica/ 23127/vox-aznar-eta-esperanza-aguirre-sergiosangiao.htm

Segurola, M. (2014, August 23). VOX investigará las facturas de su presidente, González Quirós [VOX will investigate the invoices of its president, González Quirós]. El Mundo. https://www.elmundo.es/ espana/2014/08/23/53f7ba46ca4741f40e8b 456b.html

Sosa, C. (2018, April 17). Abascal (VOX): "No es lo mismo un inmigrante hispanoamericano que la inmigración de los países islámicos" [Abascal (VOX): "A Hispanic American immigrant is not the same as immigration from Islamic countries"]. El Diario. https://www.eldiario.es/canariasahora/sociedad/ video-abascal-vox-hispanoamericano-inmigracion_ 1_2166996.html

Thorlakson, L. (2009). Patterns of party integration, influence and autonomy in seven federations. Party Politics, 15(2), 157-177.

Torres, J. (2020, March 5). VOX recibió unos 10 millones en dinero público en 2019 pese a su discurso "antichiringuitos" [VOX received about 10 million in public money in 2019 despite its "anti-beach bar (gravy train)" speech]. Cadena Ser. https://cadenaser. com/ser/2020/03/05/politica/1583393147_ 007666.html

Turnbull-Dugarte, S., Rama, J., \& Santana, A. (2020). The Baskerville's dog suddenly started barking: Voting for VOX in the 2019 Spanish general elections. Political Research Exchange, 2(1). https://doi.org/ 10.1080/2474736X.2020.1781543

Turnbull-Dugarte, S. J. (2019a). Explaining the end of Spanish exceptionalism and electoral support for VOX. Research \& Politics, 6(2), 1-8. https://doi.org/ $10.1177 \% 2 F 2053168019851680$

Turnbull-Dugarte, S. J. (2019b). Selfies, policies, or votes? Political party use of Instagram in the 2015 and 2016 Spanish general elections. Social Media + Society, 5(2), 1-15.

Valls, F. H. (2018, December 10). VOX hace caja tras las andaluzas: Dispara la afiliación en un $25 \%$ y las donaciones [VOX makes cash after the Andalusian elections: It increases membership by $25 \%$ and donations]. La Información. https://www.lainformacion. com/espana/vox-ingresos-afiliados-donacionesandalucia/6459199/?autoref=true 
Valls, F. H. (2020, January 4). El año de VOX: 56.786 afiliados, ficha una firma de cazatalentos y se profesionaliza [The year of VOX: 56,786 affiliates, signs a headhunter firm and professionalizes]. La Información. https://www.lainformacion.com/espana/voxinvestidura-abascal-afiliados/6532902/?autoref= true

VOX recibió el $66 \%$ de sus ingresos de fondos públicos en 2020 [VOX received $66 \%$ of its revenue from public funds in 2020]. (2021, April 10). Heraldo. https://www.heraldo.es/noticias/nacional/2021/ 04/10/vox-recibio-de-fondos-publicos-el-66-desus-ingresos-en-2020-1483978.html?autoref=true

VOX refuerza su estructura y anuncia: "El Vox actual no tiene nada que ver con el que habrá" [VOX reinforces its structure and announces: "The current VOX has nothing to do with the one that will be"]. (2019, August 11). Infolibre. https://www.infolibre.es/ noticias/politica/2019/08/11/vox_refuerza_ estructura_anuncia_vox_actual_no_tiene_nada_ que_ver_con_que_habra_97829_1012.html

VOX. (2018). 100 medidas urgentes de VOX para
España [VOX's 100 urgent measures for Spain]. https://www.voxespana.es/noticias/100-medidasurgentes-de-vox-para-espana-20181006

VOX. (2020a). Menas, bandas latinas y ajustes de cuentas: La violencia que soportan los barrios [Menas, Latino gangs and settling of scores: The violence that neighborhoods endure]. https://www. voxespana.es/actualidad/menas-bandas-latinas-yajustes-de-cuentas-la-violencia-que-soportan-losbarrios-20200629

VOX. (2020b). VOX, único partido que defiende el fin de las subvenciones públicas a partidos políticos $y$ sindicatos [VOX, the only party that defends the end of public subsidies to political parties and unions]. https://www.voxespana.es/actualidad/vox-unicopartido-que-defiende-el-fin-de-las-subvencionespublicas-a-partidos-politicos-y-sindicatos-20200403

VOX. (2021). Cuentas anuales del ejercicio 2020, junto con el informe de auditoría [Annual accounts for the financial year 2020, together with the audit report]. https://www.voxespana.es/wp-content/uploads/ 2021/04/CCAA-2020-Informe-audit-firmados.pdf

\section{About the Authors}
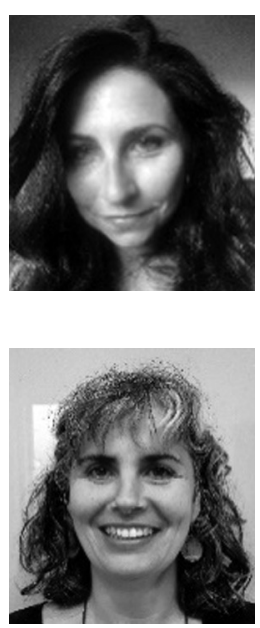

Sonia Alonso Sáenz de Oger is associate professor of political science at Georgetown University in Qatar. Her research focuses on comparative European politics, with special attention to political parties and electoral competition, centre-periphery conflict, institutions, and the political consequences of the euro crisis. She has authored articles in journals such as Party Politics, European Journal of Political Research, West European Politics, Southern European Society and Politics, Comparative European Politics, and Regional and Federal Studies. ORCID iD: 0000-0002-5094-6078

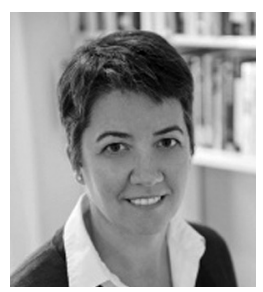

Bonnie N. Field is professor of political science in the Global Studies Department at Bentley University in Massachusetts, USA. Her research interests include governance in parliamentary regimes, political parties, legislative politics, territorial politics, and gender and politics. ORCID iD: 0000-0002-00964008. 